\title{
MENINGKATKAN KEMAMPUAN BERPIKIR KRITIS MELALUI BERMAIN SAINS PADA ANAK TK A DI LABORATORIUM PAUD YASMIN KABUPATEN JEMBER TAHUN AJARAN 2018/2019
}

\author{
Misyana $^{1}$, Indah Mayasari ${ }^{2}$ \\ Universitas Muhammadiyah Jember \\ Laboratorium PAUD Yasmin Jember \\ Email : misyana@unmuhjember.ac.id, indah.mayasari@gmail.com,
}

\begin{abstract}
ABSTRAK
Pada abad 21 dimana masyarakat sudah menggunakan teknologi, layak kalau anak-anak usia dini juga dipersiapkan untuk memiliki kemampuan yang lebih baik, utamanya di kemampuan berpikir. Sudah saatnya anak diberikan kegiatan yang lebih menantang dan menggunakan strategi yang tepat sehingga kemampuan anak benar-benar dapat meningkat lebih baik. Salah satu upaya untuk meningkatkan kemampuan berpikir kritis anak melalui bermain sains, salah satu permainan yang disukai anak yaitu bermain balon. Strategi yang dipergunakan untuk meningkatkan kemampuan anak, pemecahan masalah (problem solving) dan penemuan terbimbing (Guided Discovery). Masalah yang akan dipecahkan pada tindakan ini adalah bagaimana permainan sains dapat meningkatkan kemampuan berpikir kritis anak, pada kelompok A (4-5 tahun) di Laboratorium Paud Yasmin Jember tahun ajaran 2018/2019. Adapun jenis penelitian yang dilakukan peneliti adalah tindakan kelas, metode pengumpulan data yang digunakan dalam penelitian kali ini peneliti sebagai guru dan guru sebagai observer, wawancara dan dokumentasi. Data yang dikumpulkan berupa aktivitas anak selama kegiatan bermain sains, hasil wawancara dengan anak dan guru kelompok A. Berdasarkan hasil penelitian dapat disimpulkan bahwa bermain sains dapat meningkatkan keterampilan berpikir kritis secara signivikan. Secara klasikal dari 15 anak terdapat 13 anak yang berkembang kemampuan berpikir kritisnya secara individual dan 2 anak yang belum berkembang. Diketahui perkembangan kemampuan berpikir kritis anak secara klasikal yang diperoleh $86,66 \%$ yang berarti perkembangan kemampuan berpikir kritis anak kelompok A secara klasikal tercapai.
\end{abstract}

Kata Kunci: berfikir kritis, bermain sains, PAUD.

\begin{abstract}
In the 21st century where people have used technology, it is feasible that early childhood are also prepared to have better abilities, especially being able to think. It's time for children to be given more challenging activities and use the right strategies, and the children ability can really improve better. One of the efforts to improve children's critical thinking skills through playing science, one of the games that children love is playing balloons. Strategies used to improve children's ability, problem solving and guided discovery. The problem that will be solved in this action is how the game of science can improve children's critical thinking skills, in group A (4-5 years) in the Laboratory of Paud Yasmin Jember 2018/2019 academic year. The type of lecturers conducted is class action lectures, data collection methods used in this lecture are observation, interviews and documentation. Data collected in the form of children activities during science playing activities, results of interviews with children and teacher of group A. Based on the results of lecturers, it can be concluded that playing science can improve critical thinking skills in a significant way. Classically from 15 children there are 13 children who develop their critical thinking skills, and 2 children are undeveloped. It is known that the development of children
\end{abstract}


MISYANA, INDAH MAYASARI. MENINGKATKAN KEMAMPUAN BERPIKIR KRITISMELALUI BERMAIN SAINS DI LABORATORIUM PAUD YASMIN JEMBER KABUPATEN JEMBER TAHUN AJARAN 2018/2019. Early Childhood Vol. 2 No. $2 \mathrm{~b}$, November 2018

critical thinking abilities classically is $86.66 \%$ which means that the development of children critical thinking abilities in group $\mathrm{A}$ is classically achieved.

Keywords: Critical thinking, science games, PAUD.

\section{PENDAHULUAN}

Ilmu pengetahuan adalah alat yang epektif untuk dijadikan bekal anak dalam menjalani kehidupan, karena dengan ilmu pengetahuan dapat mengungkap rahasia yang ada di alam semesta, dan dapat mendekatkan manusia pada pencipta alam semesta, sehingga ilmu pengetahuan harus dikenalkan kepada anak sedini mungkin, sesuai dengan fase tumbuh kembang anak, dalam bentuk permainan-permainan science yang menarik. Sebagai contoh teori ilmu pengetahuan yang dapat dikenalkan kepada anak, diantaranya tentang hukum sebab akibat.

Elfan Fanhas Fatwa Khomaeny menyatakan, bahwa : "Parents or teachers should learn and understand about the laws of causality, if they has ability to teach the law of causality to children with varied learning methods, it can form and equip the children responsible attitude, and become the control for the child's behavior in interacting and socializing with each other".

Sebab akibat adalah salah satu teori ilmu pengetahuan (science) yang ada di alam semesta ini, dan harus ditanamkan pada anak sejak dini, sehingga anak ketika mencapai usia remaja atau dewasa mampu berfikir kritis dan argumentatif terhadap permasalahan yang dihadapinya, sehingga menjadi seorang yang kreatif, inovatif dan terbebas dari sikap "ikutikutan" atau taklid.

Peneliti melakukan observasi awal tentang kemampuan berfikir kritis terhadap anak TK A di Laboratorium Paud Yasmin Jember. Hasil observasi didapatkan bahwa $60 \%$ anak atau sebanyak 9 anak belum memiliki kemampuan berfikir kritis, dikarenakan anak belum dapat mengemukakan pendapat dari hasil pemikirannya. Selain itu dikuatkan berdasarkan informasi dari guru di ada Laboratorium Paud Yasmin Jember mengatakan, bahwa di sekolahnya terjadi permasalahan dalam perkembangan kognitif anak, terutama dalam hal kemampuan berpikir kritis.

Berdasarkan karakteristik anak TK A yang masih suka bermain, maka untuk meningkatkan berpikir kritis di TK A bisa melalui kegiatan pemecahan masalah (Problem Solving), hal tersebut dapat ditunjang dari beberapa fakta di lapangan, bahwa anak di TK A jarang 
MISYANA, INDAH MAYASARI. MENINGKATKAN KEMAMPUAN BERPIKIR KRITISMELALUI BERMAIN SAINS DI LABORATORIUM PAUD YASMIN JEMBER KABUPATEN JEMBER TAHUN AJARAN 2018/2019. Early Childhood Vol. 2 No. $2 \mathrm{~b}$, November 2018

sekali mengungkapkan pendapat mengenai suatu hal berdasarkan apa yang anak lihat dan dengar.

Berdasarkan fakta tersebut di atas, maka Peneliti menganggap bahwa kondisi kemampuan berpikir kritis pada anak, dapat ditingkatkan melalui kemampuan sains dengan cara pemecahan masalah. Hal ini sejalan dengan pemikiran (Goffin dan Tull, 1985) yang menyatakan bahwa masalah-masalah yang telah dikenal dengan baik oleh anak, dapat digunakan dan akan lebih mudah untuk dipecahkan oleh anak serta dirumuskan kesimpulannya. Berdasarkan uraian di atas, maka peneliti fokus pada "Bagaimanakah sains dapat meningkatkan kemampuan berpikir kritis pada anak TK A di Laboratorium Paud Yasmin Jember?'

Pembatasan konsep istilah yang dipakai dalam penelitian ini sebagai berikut:

Berpikir kritis merupakan bagian dari perkembangan kognitif setiap individu, beberapa indikator berpikir kritis anak usia dini, yaitu : kemampuan mengamati dan menganalisis; kemampuan bertanya dan memahami pertanyaan; kemampuan memecahkan masalah untuk memutuskan tindakan; dan kemampuan berinteraksi dengan orang lain.

Sains dapat dijadikan metode pembelajaran dalam pengembangan kemampuan anak untuk berpikir kritis, kemampuan dalam mengaktualisasikan diri, menyiapkan anak dalam mengisi kehidupannya, serta mampu menumbuhkan nilai religius pada mereka (Abruscato, 1982).

Hasil penelitian ini diharapkan dapat bermanfaat bagi:

1. Bagi pendidik, dapat dijadikan bahan pertimbangan dalam memilih dan menggunakan media pembelajaran yang sesuai dengan tema, atau materi yang akan diajarkan, agar kemampuan berpikir kritis pada anak dapat meningkat.

2. Bagi peneliti, dapat menambah pengetahuan, pemahaman dan wawasan dalam memilih dan menggunakan media pembelajaran pada saat terjun ke dunia pendidikan. 
MISYANA, INDAH MAYASARI. MENINGKATKAN KEMAMPUAN BERPIKIR KRITISMELALUI BERMAIN SAINS DI LABORATORIUM PAUD YASMIN JEMBER KABUPATEN JEMBER TAHUN AJARAN 2018/2019. Early Childhood Vol. 2 No. 2b, November 2018

\section{METODE PENELITIAN}

Metode penelitian yang digunakan adalah penelitian tindakan kelas. Desain penelitian Tindakan Kelas menurut Model Kurt Lewin (dalam Sanjaya, 2013:154). Adapun rincian kegiatan pada setiap tahapnya sebagai berikut:

1. Perencanaan

Dalam tahap ini peneliti menganalisa pembelajaran yang sedang berlangsung. Peneliti harus menentukan program perbaikan dari masalah yang ditemukan.

2. Tindakan

peneliti melakukan tindakan yang sudah direncanakan yang menyangkut tahapan kegiatan, alat, media, sumber belajar, waktu, alat pengumpulan data.

3. Observasi

Pengamatan untuk mengetahui seberapa efektif tindakan atau mengumpulkan informasi tentang apa saja kelemahan tindakan yang telah dilakukan.

\section{Refleksi}

$$
\text { Peneliti menganalisis }
$$

tentang hasil observasi, sehingga memunculkan program atau perencanaan baru.
Target yang ingin dicapai dalam penelitian tindakan kelas ini adalah $80 \%$ atau sejumlah 12 anak yang mengalami perkembangan dalam kemampuan berfikir kritis.

\section{HASIL DAN PEMBAHASAN}

\section{Siklus I}

Pada siklus I peneliti setelah melakukan perencanaan yang matang, kemudian melaksanakan tindakan kelas pada anak TK A di Laboratorium Paud Yasmin Jember sesuai dengan perencanaan yang dibuat, yaitu anak melihat tayangan video yang diberikan guru tentang tukang balon, anak secara interaktif diajak untuk memunculkan pendapat mereka tentang balon yang dapat terbang dan yang tidak dapat terbang.

Berdasarkan hasil evaluasi di akhir tindakan kelas yaitu pada pertemuan ketiga, maka diperoleh data sebagai berikut : anak yang mengalami perkembangan kemampuan berfikir kritis, dalam hal ini adalah kemampuan anak untuk membedakan antara balon yang dapat terbang dan yang tidak dapat terbang.

Sebanyak 9 anak atau $60 \%$ memiliki kemampuan untuk 
MISYANA, INDAH MAYASARI. MENINGKATKAN KEMAMPUAN BERPIKIR KRITISMELALUI BERMAIN SAINS DI LABORATORIUM PAUD YASMIN JEMBER KABUPATEN JEMBER TAHUN AJARAN 2018/2019. Early Childhood Vol. 2 No. $2 \mathrm{~b}$, November 2018

membedakan antara balon yang dapat terbang dan yang tidak dapat terbang, sehingga dinyatakan telah berkembang sesuai harapan, sedangkan 6 anak atau $40 \%$ belum memiliki kemampuan untuk membedakan antara balon yang dapat terbang dan yang tidak dapat terbang, sehingga dinyatakan belum berkembang sesuai dengan harapan.

Kesimpulan yang diperoleh dari hasil refleksi pada siklus I, anak yang mengalami perkembangan dalam berfikir kritis, berupa kemampuan untuk membedakan antara balon yang dapat terbang dan yang tidak dapat terbang, baru mencapai $60 \%$ atau sebanyak 9 anak, hal ini masih dibawah target capaian yang ditetapkan yaitu $80 \%$, sehingga harus ditindaklanjuti dengan penelitian tindakan kelas siklus II.

\section{Siklus II}

Pada siklus II, berdasarkan hasil refleksi siklus I, peneliti melakukan perencanaan siklus II yang matang, kemudian melaksanakan tindakan kelas pada anak TK A di Laboratorium Paud Yasmin Jember sesuai dengan perencanaan yang dibuat. Berdasarkan hasil evaluasi, diperoleh data sebagai berikut : anak yang mengalami perkembangan kemampuan berfikir kritis, dalam hal ini adalah kemampuan anak untuk membedakan antara balon yang dapat terbang dan yang tidak dapat terbang.

Sebanyak 13 anak atau 86,66\% memiliki kemampuan untuk membedakan antara balon yang dapat terbang dan yang tidak dapat terbang, sehingga dinyatakan telah berkembang sesuai harapan, sedangkan 2 anak atau $13,34 \%$ belum memiliki kemampuan untuk membedakan antara balon yang dapat terbang dan yang tidak dapat terbang, sehingga dinyatakan belum berkembang sesuai dengan harapan.

Kesimpulan yang diperoleh dari hasil refleksi pada siklus II, anak yang mengalami perkembangan dalam berfikir kritis, berupa kemampuan untuk membedakan antara balon yang dapat terbang dan yang tidak dapat terbang, telah mencapai $86,66 \%$ atau sebanyak 13 anak, hal ini berada di atas target capaian yang ditetapkan yaitu $80 \%$, sehingga tindakan kelas dinyatakan cukup dan tidak perlu adanya penelitian tindakan kelas siklus selanjutnya, karena pada siklus II kemampuan berfikir kritis anak TK A 
MISYANA, INDAH MAYASARI. MENINGKATKAN KEMAMPUAN BERPIKIR KRITISMELALUI BERMAIN SAINS DI LABORATORIUM PAUD YASMIN JEMBER KABUPATEN JEMBER TAHUN AJARAN 2018/2019. Early Childhood Vol. 2 No. 2b, November 2018

di Laboratorium Paud Yasmin Jember telah melebihi target pencapaian minimum, sehingga disepakati bersama antara peneliti dan observer (guru mitra) untuk menghentikan penelitian, dan tidak melanjutkannya pada siklus berikutnya.

\section{SIMPULAN}

Kesimpulan penelitian ini adalah, kemampuan berpikir kritis anak TK A di Laboratorium PAUD Yasmin Jember tahun ajaran 2018/2019, dapat ditingkatkan melalui permainan sains. Berdasarkan penelitian tindakan kelas yang dilakukan pada siklus I, Sebanyak 9 anak atau $60 \%$ memiliki kemampuan untuk membedakan antara balon yang dapat terbang dan yang tidak dapat terbang, sehingga dinyatakan telah berkembang sesuai harapan, sedangkan 6 anak atau $40 \%$ belum memiliki kemampuan untuk membedakan antara balon yang dapat terbang dan yang tidak dapat terbang, sehingga dinyatakan belum berkembang sesuai dengan harapan.

Pada siklus II Sebanyak 13 anak atau 86,66\% memiliki kemampuan untuk membedakan antara balon yang dapat terbang dan yang tidak dapat terbang, sehingga dinyatakan telah berkembang sesuai harapan, sedangkan 2 anak atau $13,34 \%$ belum memiliki kemampuan untuk membedakan antara balon yang dapat terbang dan yang tidak dapat terbang, sehingga dinyatakan belum berkembang sesuai dengan harapan.

Hasil siklus II berada di atas target capaian yang ditetapkan yaitu $80 \%$, sehingga setelah dilakukan tindakan dengan 2 siklus, kemampuan berfikir anak mengalami peningkatan yang signifikan.

Berdasarkan uraian di atas, maka peneliti memberikan saran yaitu:

1. Bagi guru sebagai mitra dalam kegiatan ini, dapat digunakan sebagai referensi untuk dapat menerapkan kegiatan sains sebagai tuntutan dalam Kurikulum 13 terutama dalam hal mengembangkan kemampuan berpikir kritis.

2. Bagi lembaga, proses pembelajaran di lembaga harus lebih memberikan tantangan dan menarik bagi anak, sehingga pengalaman nyata yang diperoleh anak dapat membekali anak pada masa yang akan datang 
MISYANA, INDAH MAYASARI. MENINGKATKAN KEMAMPUAN BERPIKIR KRITISMELALUI BERMAIN SAINS DI LABORATORIUM PAUD YASMIN JEMBER KABUPATEN JEMBER TAHUN AJARAN 2018/2019. Early Childhood Vol. 2 No. 2 b, November 2018

DAFTAR PUSTAKA

Ahmadah, Ismi. 2017. Meningkatkan Ketrampilan Berpikir Kritis Anak Kelompok B1 Melalui Pendekatan Sainstifik Di TK Al-Kautsar Balung Jember. (Skripsi tidak diterbitkan) : Universitas Muhammadiyah Jember.

Jackman, Hilda L. 2012. Early Education Curriculum A Child's Connection To The World. USA: Cengange Learning.

Khomaeny, Elfan Fanhas Fatwa; Sofyan , Iyan; Nugraha, Fajar. Introducing The Law of Causality to The early Childhood. Surakarta : Proceeding of International Conference On Child-Friendly Education. ISSN: 2503-5185.

Nugraha, Ali. 2008. Pengembangan Pembelajarn Sains Pada Anak Usia Dini. Bandung: JILSI Foundation.

Sani, Ridwan. 2015. Pembelajaran Sainstifik Untuk Implementasi Kurikulum 2013. Jakarta: Perpustakaan Nasional.

Sanjaya, Wina. 2014. Penelitian Pendidikan Jenis, Metode,
Prosedur.Jakarta: Kencana Prenada Media Group.

Santrock, John W. 2009. Psikologi pendidikan Education Pshychologi.Jakarta: Penerbit Salemba Humanika.

Surya, Mohamad. $2015 \quad$ Strategi Kognitif dalam Strategi Pembelajaran.. Bandung : Alfabeta.

Wardhani, W.D.L. 2016. Model Antisipasi Bencana Banjir Bandang Berbasis Pendekatan Proyek (Disertasi tidak diterbitkan). Jakarta : Universitas Negeri Jakarta 